nuclear test site locations in map drawings of Nevada, the South Pacific, Mississippi, and Alaska.

Anthropologist Catherine Lutz interviews slavick concerning the exhibited map drawings. Several statements in this interview are instrumental to understanding slavick's motivations, concerns, and point of view. Slavick states that " $[\mathrm{t}]$ he drawings are also beautifully aerial to seduce and trap the potentially apathetic viewer, so that she will take a closer look, slow down, and contemplate the accompanying information that may implicate her. I also chose the aerial view to align myself, as an American, with the pilots dropping the bombs, even though I would not drop them. As a photographer aware of the military's use of the aerial view that flight and photography provide, using the aerial view seems like a natural choice. I utilize surveillance imagery, military sources and battle plans, photography and maps, much of which is from an aerial perspective" (97). She feels that her drawn maps "are a visual interpretation or depiction of, reaction against, reflection on, and emotional response to the world around us" (99). She also comments upon how her artworks "protest the age-old power of maps; power utilized by governments and individuals in the name of private ownership, border control, and imperialism" (100).

While slavick's slim volume is aimed more at the general public than at our profession, cartographers should be aware of how maps can be used in art and elsewhere to transmit powerful messages to the viewing public. Hers are not maps to be judged on their accuracy; nonetheless, they are drawings to spatially communicate the fractures and effects of war and war preparations. Indeed, her maps are terrific or terrible reminders of the manner in which spatial data and imagery are displayed, be it in historical atlases of war or in art exhibits.

\section{Bomb After Bomb: A Violent Cartography}

by elin o'Hara slavick

foreword by Howard Zinn, essay by Carol Mavor, interview by Catherine Lutz.

Milano, Italy, Edizioni Charta, 2007.

111 pp., 13 figures, 48 plates, annotations, endnotes, author's bibliography, sources, exhibitions.

$\$ 34.95$. Softbound

ISBN 9788881586332

Reviewed by Mark Denil

Cartographer at Large

Bomb after Bomb is an atlas of aggression. It is built around a folio of individual maps depicting sites of bombings carried out by United States government agencies-primarily federal military agencies, but in one case a domestic municipal police force. As a thematic atlas, it is a clear and well-focused compendium of individual works that hangs together exceptionally well and carries a forceful and unambiguous argument about its central issue. This book should be on the shelf, and regularly in the hands, of every practicing cartographer.

This small $\left(6 \frac{3}{4} \times 9 \frac{1}{2}\right.$ inches, $1 / 2$ inch thick) atlas is divided into six sections. A foreward by the historian Howard Zinn introduces the work, and a longer essay by British art historian Carol Mavor frames some of the issues that could be raised by the works for an engaged reader or viewer. The forty-eight map works selected from the series Protesting Cartography: Places the United States Has Bombed make up the bulk of the volume with one work to each page, except for a single two-page spread and three pages given over to lightly manipulated source material. Each original map is $30 \times 22$ inches, and each is reproduced in color on the page at $5 \frac{1}{2} \times 4$ inches (except, of course, the one double spread). After the maps comes a short section of annotations for each work, which is itself followed by an interview with the artist carried out by Catherine Lutz (co-author, with Jane Collins, of the book Reading National Geographic). Bomb after Bomb closes with an appendix that includes a short biography, a bibliography, and list of exhibitions for the artist, plus source notes for the works and annotations.

The maps themselves are produced in ink and watercolor on Arches paper. In most of the works, a ground of color stains and blotches is overlaid with linear drawing and more hard-edged colored areas, often outlined (cloisonné). The source material is either another map or an aerial photograph, and often some vestige of that source is carried into the final work: an unlabeled grid (The Firebombing of Tokyo, Japan, 1945 (53)), the wreckage of assorted map furniture (Eniwetok Atoll, Republic of the Marshall Islands, 1948-1958 (55)), troop movement arrows (D-Day or Invasion Beaches, Normandy, France, Operation Overlord, 1944 (45)), or a hand-drawn photogram metric aid (Hypocenter in $\mathrm{Hi}$ roshima, Japan, 1945 (48)). Some, like Johnston Atoll, US, 1958-1962 (62), are clearly based on high oblique photo images. Slavick's maps themselves are tortured and stricken, echoing or displaying the fate of the represented place. The stains and streaks evoke explosions and conflict, and the smeared and bleeding line work connotes the smashing and smearing of the land and infrastructure by high explosive.

Certainly, this is not the usual type of publication one finds reviewed in Cartographic Perspectives. Similarly, elin slavick's presentation at the 2007 NACIS conference (and, indeed, the entire presentation session of which it was a part) was not the usual fare one expects at a cartographic conference. Nonethe- 
less, Bomb after Bomb is the kind of work with which it is advantageous for a practicing cartographer to be familiar. But why should that be? Only a tiny fraction of mapping jobs involves such topics and situations, and in general one is enjoined to present maps that appear dispassionate and detached. Nonetheless, these maps deal with "facts on the ground," facts that can be presented cartographically but whose expression may well not fall within the day-to-day vocabulary of many cartographers.

No one, or at least no one in the cartographic community, would mistake this for the work of a professional cartographer. The work abounds with cartographic naivete and innocence; for instance, the only map with a recognizable graticule (the only world map in the collection) has landmasses clearly lifted from some other projection and some sections of the landmasses seem to owe more to the era of Al-Idrisi than to more recent centuries. The map of Christmas Island (Kiritimati) on page 68 was also a little confusing, and I puzzled over it for some time. I have myself mapped that island, and the country of Kiribati of which it is a part, and this just didn't look right. It finally dawned on me that this was a different Christmas Island: the one in the Indian Ocean, south of Java, and controlled by Australia (it is where the Australians imprison their "illegal" immigrants, amongst the hills of guano), and not the island south of Hawaii in the Pacific, where the bombs went off!

Why then, would this book be of any interest whatsoever to a cartographer? That reason lies in its facile evocation of the power of maps in the service of a proposition. We know that all maps forward a position of some sort; they are rhetorical constructs that place a cogent, accessible, and persuasive argument before an audience. They naturalize a parochial position and allow or encourage the map user to internalize that position as truth. This Bomb after Bomb does with aplomb. I would compare this atlas to J. F. Horrabin's 1935 An Atlas of Current Affairs, a similarly small book of maps with short explanations of the history and situation for the very many flashpoints around the world at that time. Yes, the style is quite different; yes, Horrabin's captions are more loquacious; yes, there is any number of differences: yet, each atlas centralizes and makes obvious and natural a particular worldview (as it happens, not too very different ones).

Perhaps this power is reinforced by the atlas format; one wonders if individual works would be as powerful alone; although, on the other hand, at full size slavick's individual works would be $5^{1 / 2}$ times larger.

Zinn's foreward focuses on the visceral response evoked by slavick's work. He writes of how these maps had the power to stun him by foregrounding the effects, results, and consequences of the very sort of bombing missions in which Zinn himself had played so significant a part in the 1940's. As a bombardier, he would, without a doubt, have seen and handled a good many maps in the course of his tasks, charts focused on the assigned target as just that: a target. Such maps strictly circumscribe the reality on the ground, and do not allow infiltration of anything that might distract from the job at hand (such as contemplation of the consequences of actions). Slavick's maps, by contrast, come freighted with poignancy: consequence is writ large upon them.

This freighting occurs due, in part, to the way slavick's maps grow from and subvert the more recognized and expected forms of map. What elin slavick does is to manipulate the outward trappings and accouterments of what is generally a strictly formalized and tightly structured form to produce something all the more startling for its familiarity. The very maps the artist sources are the ones the planners and perpetrators of the actions employed. It is into this "dispassionate" material that slavick inserts the boot marks of the players. It breaks the "clean-cut" image of the map and makes strange the familiar. This observation is hardly a new one (all the texts in Bomb After Bomb mention it in some manner or form), and it is often mentioned in discussions of "map art," but it is, in this case, quite apt.

The breaking of the familiar (the unexpected subversion, the failure of the trusted strength) has a power of its own, and when the legitimacy of familiarity is as strongly entrenched in the psyche as is official or military mapping (and the more strongly accepted as it is less understood), the subversion itself is disturbing. One is reminded of the 1826 painting Greece on the Ruins of Missolonghi, by Eugène Delacroix, which depicts a young woman with her arms spread out in sadness and incomprehension, with a triumphant Turk in the background.

Zinn, Mavor, and slavick herself all refer to this subversion, sometimes obliquely, in the atlas texts. Zinn writes of the haunting knowledge of complicity born of the contrast between experiences on opposite sides of the event. In that vein, he compares it to the shock of the 2001 events and the stunned national acquiescence to the subsequent random military revenge strikes that followed.

In Mavor's series of essays, themes of memory predominate. Memories of her own, memories of others, and, eventually, fantastical memories of a highly improbable nature no one could ever have had. She seems at times quite punch drunk on the concept of memory, and in the tizzy of her passion she badly fumbles what is, no doubt, supposed to be a passage of some significance concerning pressed flowers in the pages of a dry report on the after-effects of the Hiroshima bombing. 
Despite this, and despite a few other absurdities (I am sorry, Ms. Mavor, airplanes did not "perfect cartography"), these essays are not a waste of time. Her comparison of these works to the map works of Yves Klein is useful, and the parallel of maps with the power of Gilles Deleuze's Sensuous Sign is apt (albeit barely explored).

The Lutz interview, "What We Cannot See," is of greater interest than Mavor's essays. In the interview slavick is able to discuss her working method, the origins and development of this series of paintings, and the relation of these works with other works in her oeuvre. Her discussion of the decision to employ drawing, painting, and the abstraction of the map form is especially interesting. She worries "about the use of abstraction to address such a magnitude of destruction"(98), and quotes W. G. Sebald about the "the construction of aesthetic or pseudo-aesthetic effects from the ruins of an annihilated world" (98). Her references to Goya's Disasters of War, Picasso's Guerni$c a$, and the work of Sue Coe address the aesthetic, but not, I think, the abstraction issue. Slavick's discussion of the decision to employ the map form, that abstractly extreme, strictly formalized, semantically rich, semiotically complex, historically laden, and culturally embedded class of text and image making, is rather lightly passed over (in a single sentence) as protest against hegemonic power. Perhaps this lack of examination is not so very surprising. There is little enough in either the cartographic or art literature dealing with the underlying motivations for such a decision, and much of what has been written tends not to be particularly helpful.

Examined critically or not, ontological cartographic issues raised by these maps are significant. All maps carry intention; no map has been made, or could ever be made, innocent of intention (which is not to say a map may not be discovered in a seemingly unintentional artifact - but that discussion is for another day, but any map reading is an intersection of intentionality between the preparer of the artifact (the map maker) and the user (map reader). Each party is capable of leading interpretation and of hijacking interpretation through manipulation of expectations and evidence, and either party can accept, ignore, or subvert the conventions and paradigms. We have seen many, varied examples of this, amongst them: Gordon and Del Tredici's Nuclear Map of Canada, NoZone IX (Empire), Counter Cartographies Collective's disOrientation Guide, and now Bomb After Bomb.

A cartographer generally has a collection of resource materials: technical manuals, various data tables, some drafting implements (I hope I am not dating myself with that one), and, amongst the most useful, maps, lots of maps. Examining, consulting, measuring, and simply looking at maps is part of what keeps the cartographic practitioner connected to his or her practice and alive to possibilities. One should see slavick's Bomb After Bomb as a useful and thought-provoking atlas that could hold a place in any cartographer's resource collection. It would hold this place not only for its thematic content, but as an example of a reasonable, accessible, and persuasive way of making maps. All maps should not look like these; of course not-no more than all maps should look any particular way, but Bomb After Bomb shows us valuable ways a map can look.

\section{References}

Blechman, Nicholas, ed. 2004. NoZone IX (Empire). New York: Princeton Architectural Press.

Canadian Coalition for Nuclear Responsibility.1998. Nuclear map of Canada. http://www.ccnr.org/nuclear map/index.html.

Counter Cartographies Collective. 2006. disOrientation guide. University of North Carolina. http://www. countercartographies.org/projects/remapping-theuniversity/disorientation-guide-2006.html.

de Goya, Francisco. c.1810-1811. Desastre de la guerra (Disasters of war), 39; Grande bazana! con muertos! Etching and aquatint. From Olga's Gallery, http://www. abcgallery.com/G/goya/goya146.html.

Delacroix, Eugène. 1826. Greece on the ruins of Missolonghi. Oil on canvas. From Olga's Gallery, http:// www.abcgallery.com/D/delacroix/delacroix1.html. Horrabin, J. F. 1935. An Atlas of current affairs. 2nd ed. New York: Knopf.

Lutz, Catherine A., and Jane L. 1993. Reading National Geographic. Chicago: University of Chicago Press.

Picasso, Pablo. 1937. Guernica. Oil on canvas. From Olga's Gallery, http://www.abcgallery.com/P/picasso/picasso36.html. 